Esta publicación cientifica en formato digital es continuidad de la revista impresa ISSN-Versión Impresa 0798-1406 / ISSN-Versión on line 2542-3185Depósito legal pp
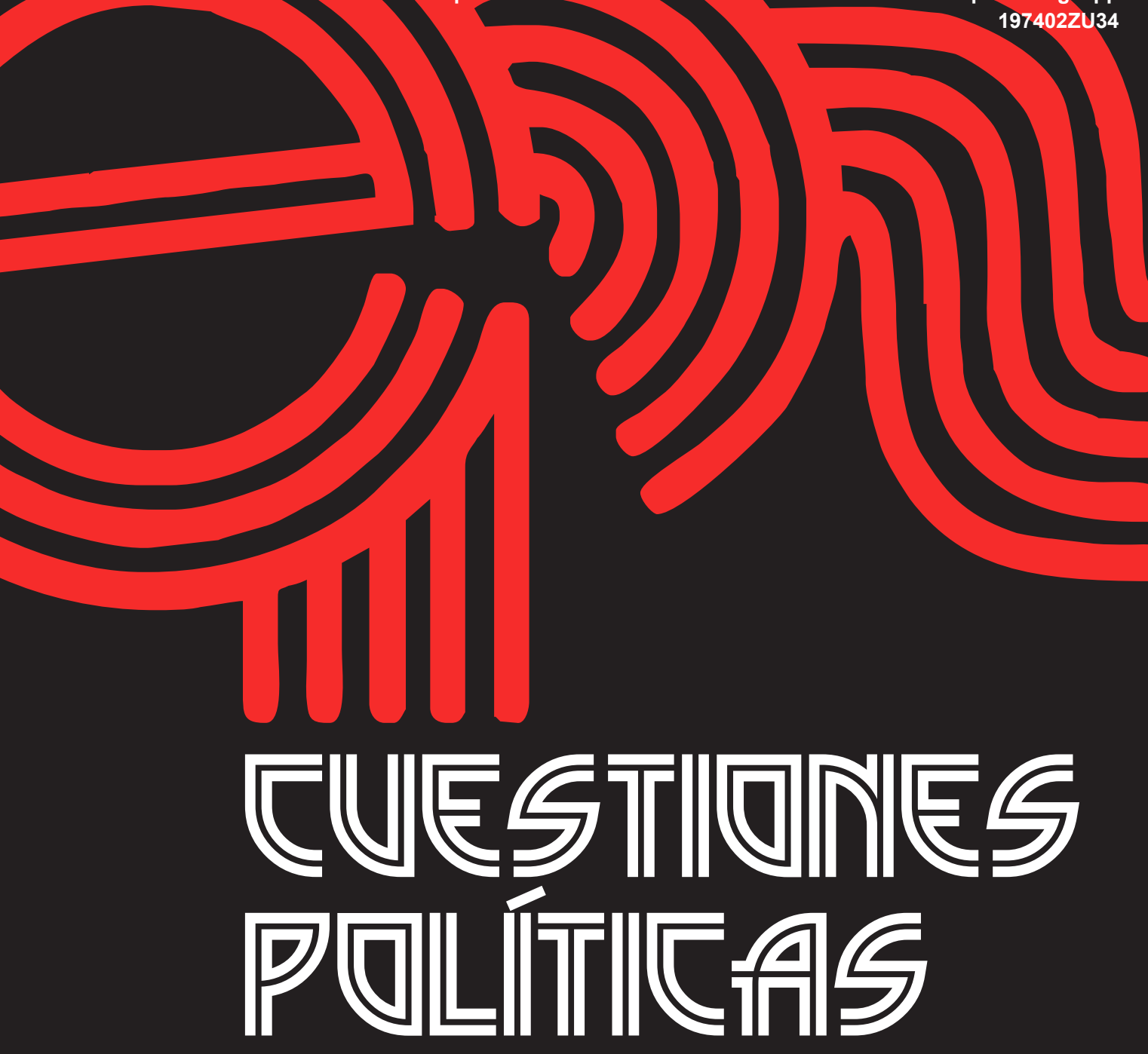

Instituto de Estudios Políticos y Derecho Público "Dr. Humberto J. La Roche" de la Facultad de Ciencias Jurídicas y Políticas de la Universidad del Zulia Maracaibo, Venezuela
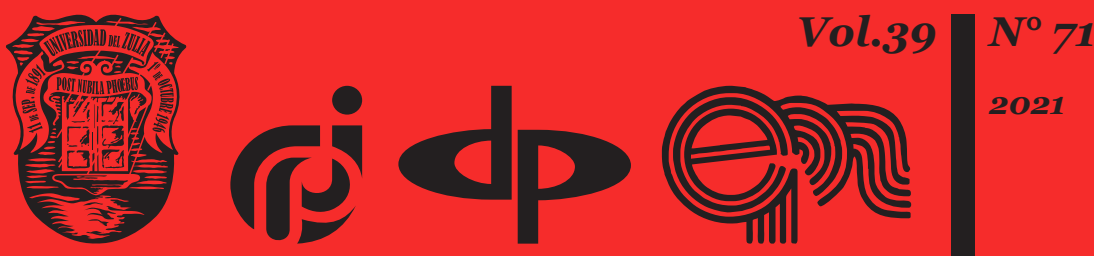


\title{
Criminal Liability of Legal Entities for Environmental Crimes: Problems of Law Enforcement Practice
}

\author{
DOI: https://doi.org/10.46398/cuestpol.3971.11
}

\author{
Yuliia O. Danyleuska * \\ Tetiana A. Sokur ** \\ Oleksandr M. Bodnaruk *** \\ Andrii V. Shevchuk \\ Oleksiy V.Stratiy $* * * * *$
}

\section{Abstract}

The aim of the article was to conduct a comparative legal analysis of the features and problems of criminal prosecution of legal entities for environmental crimes. The research objectives were fulfilled through modern methods of cognition. The leading practical method was the method of observation. The study allowed to form a conceptual understanding of theoretical ideas about environmental crimes of legal entities in Ukraine. Currently, Ukraine is trying to focus in its legislative innovations on the implementation of progressive approaches to the introduction of a comprehensive institution of criminal law measures regarding the liability of these entities. Relevant legal mechanisms and comments identified in the practice of the European Union and substantiated by scholars, can be implemented in the legislation of Ukraine. Amendments to the rules governing the procedure for effective prevention of environmental crimes by legal entities are proposed. It seems reasonable to introduce an active monitoring analysis of anthropogenic activities of companies, and the creation of special units to identify relevant violations. The mechanisms for implementing the set of preventive and

* PhD in Law, Senior Researcher, Head of Graduate School of Donetsk Law Institute of the Ministry of Internal Affairs of Ukraine, 87510, Mariupol, Ukraine. ORCID ID: https://orcid.org/oooo-0002-18938473

** PhD in Law, Associate Professor at the Department of Criminal, Civil and International Law, Law Faculty, Law and Management Institute, Zaporizhzhia Polytechnic National University, 69063, Zaporizhzhia, Ukraine. ORCID ID: https://orcid.org/oooo-0oo2-2061-2229

*** PhD in Law, Associate Professor at the Department of Criminal Law, Faculty of Law, Yuriy Fedkovych Chernivtsi National University, 58012, Chernivtsi, Ukraine. ORCID ID: https://orcid.org/oooo-00030752-8011

**** PhD in Law, Associate Professor at the Department of Criminal Law, Faculty of Law, Yuriy Fedkovych Chernivtsi National University, 58012, Chernivtsi, Ukraine. ORCID ID: https://orcid.org/oooo-0oo34501-0440

**** PhD in Law, Assistant at the Department of Criminal Law, Faculty of Law, Yuriy Fedkovych Chernivtsi National University, 58012, Chernivtsi, Ukraine. ORCID ID: https://orcid.org/oooo-ooo1-8381-2677 
monitoring measures outlined in the article, set the background for further scientific research.

Keywords: environmental crime; criminal liability; anthropogenic impact; legal entities; environmental crime.

\section{Responsabilidad Penal de las Personas Jurídicas por Delitos Ambientales: Problemas de la Práctica Policial}

\section{Resumen}

El objetivo del artículo fue realizar un análisis jurídico comparado de las características y problemas de la persecución penal de las personas jurídicas por delitos ambientales. Los objetivos de la investigación se cumplieron mediante métodos modernos de cognición. El método práctico principal fue el método de observación. El estudio permitió además formar una comprensión conceptual de las ideas teóricas sobre los delitos ambientales de las personas jurídicas en Ucrania. Actualmente, Ucrania está tratando de centrar sus innovaciones legislativas en la aplicación de enfoques progresivos para la introducción de una institución integral de medidas de derecho penal en relación con la responsabilidad de estas entidades. Los mecanismos legales relevantes y los comentarios identificados en la práctica de la Unión Europea y fundamentados por académicos pueden implementarse en la legislación de Ucrania. En particular, se proponen modificaciones a las normas que rigen el procedimiento para la prevención efectiva de delitos ambientales por personas jurídicas. Parece razonable introducir un análisis de seguimiento activo de las actividades antropogénicas de las empresas y la creación de unidades especiales para identificar violaciones relevantes. Los mecanismos para implementar el conjunto de medidas preventivas y de seguimiento esbozadas en el artículo forman el marco para futuras investigaciones científicas.

Palabras clave: delito ambiental; responsabilidad penal; impacto antropogénico; entidades legales; delito ambiental.

\section{Introduction}

In the $21^{\text {st }}$ century, humanity has faced specific threats to the environment due to air, water and soil pollution, declining species diversity and climate change. These trends contribute to the creation of an appropriate legal framework and strengthen liability for environmental damage (Sirant, 
2020). Ecosystem protection has been the subject of numerous national, supranational, and international legal norms. The global nature of the environmental crisis necessitates high-quality reform of national legislation in different countries and the strengthening of criminal liability for environmental crimes. Moreover, the effects of the COVID-19 pandemic, including global economic uncertainty, rising unemployment, trade disruptions, and increased government incentives have increased the risk of corporate crime as such (Kerrigan et al., 2021).

The world's leading countries note the need to create a harmonized legal, regulatory, methodological, and organizational framework that meets the requirements of national and European environmental security (Ladychenko et al., 2019). In recent decades, the international community has stepped up its response to environmental challenges. The world community pays special attention to the anthropogenic impact of economic activity on national and transboundary ecosystems, which leads to increased ecologization of production processes at the global and regional levels (Lynch, 2020). Environmental management is becoming an integral part of the activities of legal entities in different countries. Moreover, the ecologization of production is recognized as the most important indicator of progress in approaches to business development (Lynch et al., 2018). However, the desire to increase profits sometimes leads to the choice of the least environmentally friendly ways of doing business. This position mostly leads to the commission of environmental crimes, the consequences of which sometimes cause irreparable damage to the environment.

The concept of criminal liability of a legal entity is spreading around the world. It can be argued that a legal entity may be liable for an act committed by its officials, agents or managers in the 21st century (Adua and Abdul-Hamid, 2018). According to Art. 10 of the UN Convention against Transnational Organized Crime, subject to compliance of a State party with the principles of the law, the liability of legal entities may be criminal, civil or administrative (United Nations Office on Drugs and Crimes, 2000), but this Convention also directly recommends to member states (including Ukraine) to introduce criminal liability of legal entities for certain criminal acts.

Environmental crime is gradually becoming a separate category of crime in criminology (White, 2018). Definitions in this area remain unclear, and the number of scientific approaches to the nature and content of liability of legal entities is constantly growing. The study of environmental crimes requires their comprehensive assessment, taking into account the global consequences of environmental destruction. A clear understanding of environmental crimes and bringing perpetrators to justice is not only important, but also necessary in the realities of the global environmental crisis. The need to legalize the results of environmental damage research 
remains a unique criminological problem (Nellemann, 2017). One of the most effective tools for solving the outlined problems is the signing of multilateral documents and, as a result, the intensification of partnerships in the environmental field. However, achieving a positive result even in the context of strengthening interstate cooperation remains ineffective. The continuing anthropogenic impact on ecosystems has made environmental security issues a particularly important item on the global political agenda.

In this context, lawmakers and practitioners increasingly support the strengthening of criminal liability for environmental crimes (Porfido, 2021). Criminalization of environmental violations and the search for the most effective sanctions become a vector of state activity for further active participation in democratic world politics (Camproux Duffrène and Jaworski, 2021). Environmental, social and governance issues increasingly got to the top on the political agenda. This trend is also reflected in the activities of companies of all sizes and types around the world.

The study of the essence of environmental crime as an object of criminological research, its main identifying features, provides an opportunity to argue that today "environmental crime" should be considered as a dangerous social phenomenon manifested in criminal behaviour prohibited by criminal law, which poses a real danger to the environment and/or its individual objects. Environmental crime is spreading rapidly, threatening not only habitats and wildlife populations, but also entire ecosystems, the environment, and even financial systems. These crimes can generate very high profits, carry a relatively low risk of detection, and are mostly committed by organized criminal groups operating across internal and external borders. The rise of environmental crime, together with its transnational nature, requires a comprehensive and coordinated approach by the legislature, law enforcement and the judiciary at the national level.

It can be stated that in today's conditions the vector of centuries-old international controversy has shifted from the question of whether or not legal entities can be held criminally liable and focused its efforts on defining and regulating the relevant liability, including the one in the environmental sphere. The main reason for the introduction of criminal liability of legal entities is the increase in the number and scale of crimes against the environment committed on behalf of legal entities, at their expense or for their benefit (in their favour) by individuals. Environmental crimes are the result of legal evolution, the result of processes of social transformation in response to the public's desire to have a green legal system focused on effective protection (Lennan, 2021).

In Ukraine, the application of criminal legislation in the field of environmental protection has achieved positive results in recent years, but has revealed many difficulties, obstacles and gaps in practice. According to the results of the analysis of judicial practice, it can be stated that 
environmental crimes are the most common in the following areas: 1) industrial production (the situation with regard to waste management remains particularly critical); 2) the use of natural resources and minerals. Deforestation in Ukraine, especially the destruction of the Carpathian forests, remains an urgent problem; 3) hunting and trade in wild animals. Illegal wildlife trade is still public in Ukraine. High economic benefits brought by trade in endangered species make it difficult to prevent and combat illicit trade, etc. (Turlova, 2017:45). The institution of criminal law measures in the field of liability of legal entities has been introduced in Ukraine. The amendments to the criminal legislation of Ukraine are a novelty and, on the one hand, certainly have a positive impact on the rule of law in the environmental, economic and international spheres, but the introduction of this type of criminal liability requires more detailed study and significant changes in legislation to eliminate contradictions.

The aim of the article is a comparative analysis of problematic issues and features of the process of criminal prosecution of legal entities for environmental crimes in Ukraine and the European Union. The aim involved the following research objectives: 1) generalize doctrinal approaches to the essence and content of liability of legal entities for crimes committed in the environmental sphere; 2) identify the features and problems of bringing legal entities to justice for environmental crimes in Ukraine and in the European Union; 3) establish the most effective directions of reforming the criminal legislation of Ukraine in the studied area in the context of the European positive practice of law enforcement.

\section{Methods and Materials}

The results of the study were obtained through the use of a set of practical and methodological tools tested at each stage of scientific research. The research procedure within the stated aim of the article is shown in Figure 1.

The methodological background of the study was a set of subjectbased principles, approaches and methods of cognition. The study used a set of general scientific, philosophical and special methods that meet the objectives of the article. General scientific methods of analysis and synthesis, induction and deduction, comparison, abstraction, etc. were used in the article.

The historical-legal method was used to determine the stages, analogues and determinants of international cooperation in the field of improving the legal regulation of the studied institution. The problem-chronological method allowed to structure the text of the research, empirical analysis helped to compare the gradual expansion of the subjective composition of criminal liability for environmental crimes in Ukraine and the European Union. 


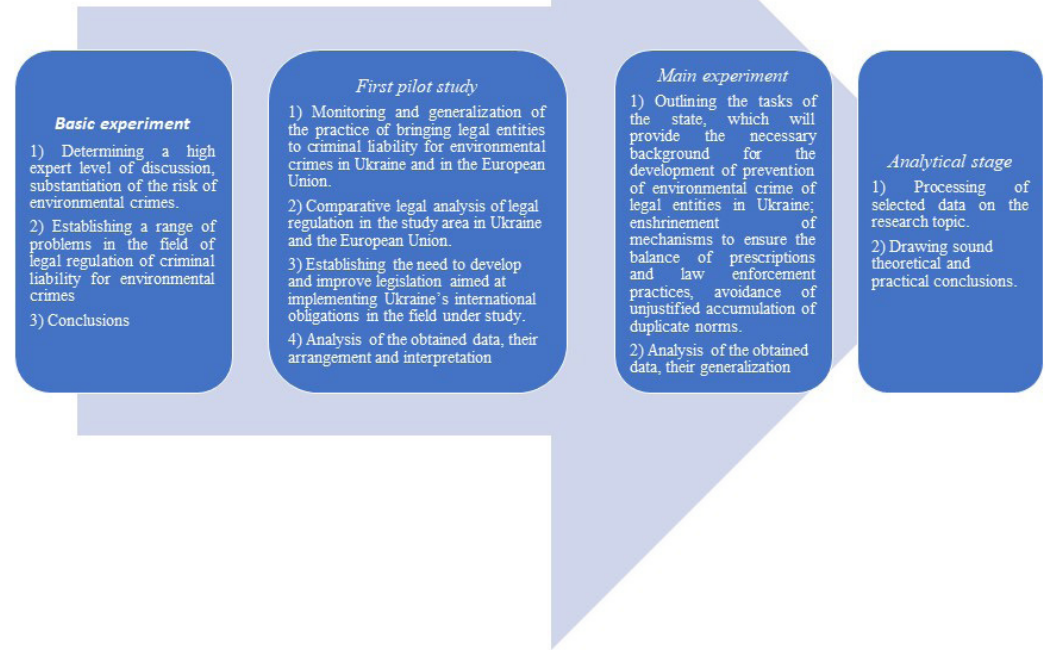

\section{Figure 1: Abstract research design Source: Authors}

The leading practical method of scientific research was the method of observation. This method allowed to reveal the following items from the author's point of view: the shortcomings of criminal liability of legal entities for environmental crimes in the EU; identify the positive aspects for Ukraine that can be taken into account in the law enforcement practice; focus on the vectors of reforming the current legislation of the European Union and Ukraine; determine the obligations of Ukraine in the adaptation of the sustainable European practice of law enforcement, and especially prevention. A special legal method of cognition - the comparative method -was also used in the research. In particular, macro-comparisons were used in the context of the importance of testing the latest foreign practices of ecologization of the economic activity of legal entities in Ukraine.

The dialectical method was the leading method of scientific research, which was based on two principles: 1) determinism (the principle of conditionality and the relationship between different phenomena); 2) historicism (any phenomenon is not static, it develops in time). The chosen method allowed to focus the scientific research on the transformation of 
scientific approaches to the essence and content of criminal liability of legal entities for environmental crimes through the prism of society and qualitative changes in modern realities of legal consciousness and law enforcement. This method also allowed to determine the state, directions, and prospects of development of scientific research and legislative developments in the studied area. The above methods allowed to identify and take into account all the factors and conditions that determined the evolution of criminal liability of legal entities for environmental crimes in Ukraine and in the EU, especially in the context of criminological and procedural aspects.

The research involved the 41 works of leading scholars of Ukraine and the European Union, among which special attention was paid to scientific research on the subject of the article, as well as the essence of criminal liability of legal entities as such. The analysis of the legal regulation of the European Union, its member states and Ukraine has become especially important. Working with authentic texts and relevant statistics allowed to form a comprehensive author's idea of the subject of the article, and to offer author's reasonable proposals for legislative innovations.

\section{Results}

The world community recognizes that the protection of the environment, the rational use of natural resources and environmental security are the key to the existence of not only the people, the nation, but humanity as a whole. That is why ensuring environmental safety and protecting the environment are becoming priorities of state policy. The practice of combating environmental crime in the territory of the European Union, including in matters of bringing legal entities to justice, seems to be quite positive. The adoption by the European Commission of the new European Green Deal, a roadmap for ensuring the sustainability of the EU economy in all segments of society (European Commission, 2021), deserves attention. In order to comply with the provisions of this document and to combat environmental crime, the European Commission adopted a number of proposals on July 14, 2021. In particular, the main vectors of the newly adopted documents stipulate that EU policy on climate, energy, transport and taxation must meet the requirements for reducing net greenhouse gas emissions by at least $55 \%$ by 2030 compared to 1990 levels. The European Green Deal was implemented because achieving this emission reduction over the next decade is crucial for Europe to become the world's first climate-neutral continent by 2050 (European Commission, 2021).

Criminal liability for environmental crimes has recently emerged in the European Union. Directive 2008/99/EC on the protection of the environment through criminal law was adopted on 24 October 2008. 
Member States were required to transpose the Directive into national law by December 2010. The Directive aims to supplement the existing system of administrative sanctions with criminal law sanctions to strengthen compliance with environmental laws. Criminal penalties demonstrate social disapproval of a qualitatively different nature from administrative penalties or compensation mechanisms under civil law (Official Journal of the European Union, 2008). It is significant that, despite the fact that thirteen years have passed since the adoption of the directive, the process of its adaptation into the national legislation of the EU Member States cannot be considered complete.

All Member States have provided for additional sanctions, such as the obligation to compensate for the damage caused, the publication of a court decision or the revocation of a certain permit. These sanctions can be very useful in addition to traditional ones, such as financial fines/penalties and prison sentences. At the same time, the parallel application of additional and basic sanctions is not ensured in Member States where courts do not have the discretion to impose additional sanctions (European Commission, 2020). Most Member States provide for the criminal liability of legal entities, with the exception of Bulgaria, Germany, Greece, Latvia and Sweden. Although the most common form of criminal sanctions imposed on legal entities is financial sanctions, additional sanctions are applied fragmentarily.

The criminal liability of corporations was enshrined in French law under Article 121-2 of the French Penal Code (1994). Corporate criminal liability was governed by the "specialty principle": companies could be prosecuted for specific offenses only if specifically provided by law. From December 31, 2005, the corporation may be held liable for any criminal offense. However, corporations can only be prosecuted for offenses committed by: "their bodies or a representative". Violations that can lead to prosecution of companies must be committed "at their expense". An action is considered to be directly related to the company if it is "aimed at ensuring the organization, operation or goals of the company". Persons whose actions have led to the prosecution of companies can also be prosecuted for the same crimes. These provisions apply to foreign companies doing business in France, provided that they are established as legal entities in accordance with French law.

Besides, the French Penal Code (1994) provides for the following penalties that may be applied to a legal entity: fine (Articles 131-38), confiscation of property (Articles 131-21), liquidation of the legal entity (Article 131-37, Article 131-39) (Legislationline, n. d.). The Finnish Criminal Code (1889) also contains an example of an objective obligation in Section 9, Section 2, paragraph 1: a legal entity may be sentenced to a fine if it has not shown due consideration in its activities and the precautions needed to prevent the offense (Ministry of Justice of Finland, 2012). 
Despite the fact that the United Kingdom is no longer an EU member, this country is effectively implementing the Directive. In particular, at the legislative level, offenders continue to be prosecuted by imposing punitive civil sanctions, the violation of which leads to criminal prosecution of legal entities (Government of the United Kingdom, 2021). The law of this country guarantees that employers or agents who have committed an environmental crime are held liable. This law enforcement practice seems to be quite effective.

It can be stated that the practical implementation of environmental criminal law and its challenges have been the subject of numerous reports by the national competent authorities of the EU member states. The analysis of these documents allowed identifying the main shortcomings of criminal liability of legal entities for environmental crimes in the European Union (Figure 2).

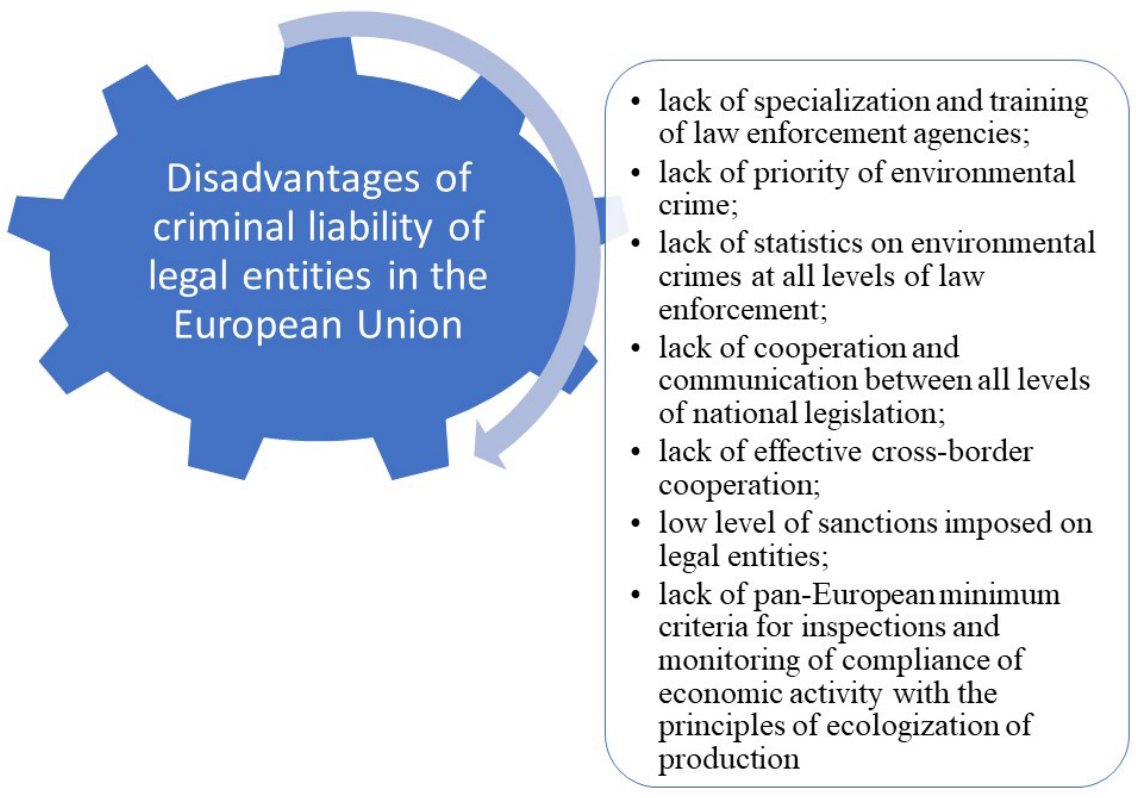
Figure 2: The main shortcomings of criminal liability of legal entities for environmental crimes in the European Union Source: Authors


It is worth noting that on January 29, 2021, Eurojust published a Report on Casework on Environmental Crime (Eurojust's, 2021). The Report provides an overview of the legal and operational problems that arise in such cases and builds on the experience gained in almost 60 cross-border cases of environmental crimes that were referred to Eurojust between 2014 and 2018. The generalized positions of this document are mainly focused on the representatives of the judiciary of the EU member states, which deal with the problems of cross-border environmental crime. At the same time, such a practice can be taken into account based on the results of adaptation on the territory of Ukraine.

The most common types of environmental crimes in the European Union include the following: 1) trade in waste; 2) trade in various species of wildlife; 3) air pollution; 4) illegal trade in dangerous chemicals; 5) dangerous contamination of food; 6) illegal construction works and related issues. Besides, environmental crimes are often accompanied by other forms of crime, such as organized crime, fraud, forgery and money laundering. In addition to these data, the Report also identifies a number of legal and operational issues in the fight against environmental crime, such as insufficient specialized knowledge and practical experience, different legislative and investigative approaches in different jurisdictions, and the multidisciplinary nature of environmental investigations (led by various specialized national administrative bodies).

The analysis of the generalizations of the European Union practice set out in the Report allowed singling out the positive aspects for Ukraine that can be taken into account in law enforcement practice: 1) competent administrative, law enforcement and judicial bodies should strive for multidisciplinary cooperation; 2) environmental crime should be recognized as organized crime; 3) it is appropriate to use international instruments of coordination and cooperation, such as joint investigation teams and the involvement of international experts at an early stage in the investigation of complex cross-border environmental crimes; 4) key concepts of environmental criminal law need further harmonization and more consistent interpretation in the context of EU practice; 5) penalties for committing environmental crimes should be harsher and become preventive.

In turn, the European Union seeks to promote a high level of environmental protection on its territory and to do its utmost to prevent environmental damage in third countries caused by companies located in EU Member States. The European Parliament has expressed concern about the wide expansion of environmental crime, as evidenced by the combined assessments of the OECD, the United Nations Office on Drugs and Crime (UNODC), the United Nations Environment Program (UNEP) and Interpol on monetary assessments of all environmental crime. Europol 
Yuliia O. Danylevska, Tetiana A. Sokur, Oleksandr M. Bodnaruk, Andrii V. Shevchuky Oleksiy V. Stratiy

recognizes that this is the fourth largest category of international crime, which is directly or indirectly related to transnational organized crime and corruption (Europol, 2020:9).

At the same time, there is currently no EU legal document that addresses the possibility of prosecuting European companies abroad for environmental crimes or activities that cause environmental damage. It seems necessary to encourage parent companies to take sustainable and responsible approaches to cooperation with third countries in accordance with international standards in the field of human rights and the environment, as well as to refrain from adopting investment strategies that directly lead to dangerous consequences.

In this context, the adoption of the European Parliament Resolution on the liability of companies for environmental damage on 21 May 2021 in Brussels (European Parliament, 2021) became quite significant. In particular, Europol declared in the document the need to: 1) develop a harmonized classification of environmental crimes; 2) the introduction of much more timely and stringent regulatory measures in the Member States; 3) introduction of a comprehensive monitoring system to ensure compliance with environmental legislation; 4) adoption of a general framework directive on environmental offenses, effective and proportionate sanctions (defining the conduct, nature of offenses, types of offenses, reparation regimes, remedial measures and minimum sanctions, including joint liability of legal entities and individuals); 5) introduction of a secondary liability regime, namely parental and chain liability for damage caused to human health and the environment; 6) the urgency of assessing the current situation with the liability of subsidiaries operating outside the EU, including possible improvements in cases of environmental damage, etc.

It can be stated that comprehensive and effective precautionary measures, deterrent and proportional criminal sanctions are important deterrents against environmental damage in the EU. At the same time, the level of detection, investigation, prosecution, and conviction for environmental crime remains relatively low. The European Union's position in the area under study remains unchanged - according to the polluter pays principle, companies must bear the full cost of the environmental damage they have directly caused to encourage them to internalize environmental factors and avoid external costs.

As part of the need to comply with international legal requirements for environmental protection and criminalization of illegal acts in this area, Ukraine signed the Convention on Environmental Protection by means of criminal law (Verkhovna Rada of Ukraine, 1998). The provisions of the Convention stipulate the types of intentional criminal offenses or illegal acts committed through negligence (including serious). Ratification of this act was a driving factor in the further introduction of criminal liability of legal 
entities for environmental crimes and the transformation of the national legal field.

At the same time, the level of environmental crime in Ukraine is gradually increasing, as evidenced by statistics (State Statistics Service of Ukraine, 2021) shown in Figure 3.

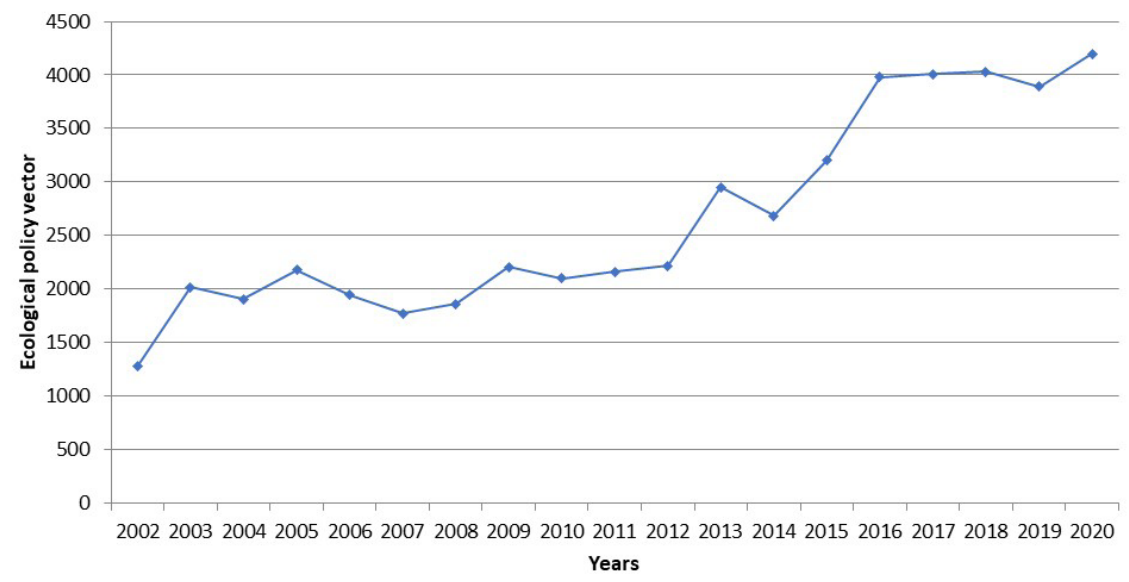

\section{Figure 3: The share of environmental crime in the overall structure of crime in Ukraine for the period from 2002 to 2020 Source: Authors}

This chart shows a gradual increase in environmental crime in historical perspective. Unfortunately, not all law enforcement reports, and statistical tables provide information on the commission of criminal offenses in the study area by legal entities, which allows forming an objective picture of the subject composition. At the same time, it is safe to say that the lack of comprehensive monitoring of environmental crimes is a negative factor in reforming law enforcement practices.

Ukraine has an institution of criminal law measures (quasi-criminal liability) regarding the liability of legal entities (Verkhovna Rada of Ukraine, 2013). At the same time, the Civil Code of Ukraine (Verkhovna Rada of Ukraine, 2003) defines a legal entity of private or public law as an organization established and registered in the manner prescribed by law, endowed with civil capacity and capacity to be a party in court.

At the same time, the Criminal Code of Ukraine (Verkhovna Rada of Ukraine, 2001) was supplemented by Section XIV-1 "Criminal Law Measures Concerning Legal Entities", amending the Criminal Procedure 
Code of Ukraine and other regulatory acts. It can be stated that it is the first time in Ukraine that criminal law measures were used against a legal entity, provided that the authorized person committed an offense on behalf of and in the interests of the legal entity.

The legislator determined that the subjects of such crimes are authorized persons of a legal entity who have committed criminal offenses under the relevant articles of the Criminal Code of Ukraine: violation of environmental safety rules (Article 236); failure to take measures to eliminate the consequences of environmental pollution (Article 237); pollution or damage to land (Article 239); illegal seizure of water fund lands on an especially large scale (Article 2392); violation of the rules of protection or use of subsoil, illegal extraction of minerals (Article 240); air pollution (Article 241) and others. It should be emphasized that Section VIII of the Criminal Code of Ukraine deals with environmental crimes.

Addressing the peculiarities of criminal liability of legal entities for environmental crimes in Ukraine, it is worth emphasizing that from the point of view of law enforcement practice, the financial form of liability is legalized and widespread - the application of penalties. In practice, the responsibility for illegal actions of a legal entity rests with its authorized persons. According to Article 96 of the Criminal Code of Ukraine authorized persons of a legal entity means officials of a legal entity, as well as other persons who have the right to act on behalf of legal entity in accordance with the law, constituent documents of a legal entity or contractual relationship. In particular, such crimes are committed directly in the interests of legal entities and lead either to improper benefit or to the creation of appropriate conditions for such benefit for the legal entity.

The legislator also considers it a crime to commit actions in the field of ecology aimed at avoiding the liability enshrined in law. Such criminal law measures as fines, confiscation of property and liquidation may be applied to legal entities.

In this case, the fine and liquidation are used as the main types of measures, while confiscation - only as an additional one. It should be noted that in 2020 the Resolution of the Verkhovna Rada of Ukraine adopted Recommendations of Parliamentary Hearings on Priorities of Environmental Policy of the Verkhovna Rada of Ukraine for the Next Five Years (Verkhovna Rada of Ukraine, 2020), which fully correlate with the Law of Ukraine No. 2697-VIII of 28.02.2019 "On the Basic Principles (Strategy) of the State Environmental Policy of Ukraine 2030" (Verkhovna Rada of Ukraine, 2019). These Recommendations provide for vectors of transformation of approaches to criminal liability of legal entities for environmental crimes, in particular, identifying not only the strengthening of responsibility, but also prevention (Figure 4). 


\section{Priorities of environmental policy of the Verkhovna Rada of Ukraine}

for the next five years

(in the context of criminal liability

of legal entities)

Stimulation of measures for ecological modernization of enterprises (preventive measures)
Legalization of the system

of extended responsibility of

the waste producer, testing

of new principles of the permit system
Strengthening the criminal

liability of enterprises for

environmental pollution

Figure 4: Priorities of the environmental policy of the Verkhovna Rada of Ukraine for the next five years (in the context of criminal liability of legal entities)

It can be noted that Ukraine has chosen the path by analogy with the legalization of criminal liability of legal entities for environmental crimes in the European Union. This approach of the legislator seems extremely progressive and deserves support. However, despite the fact that environmental issues are regulated by more than 40 laws and hundreds of bylaws in Ukraine, the system of liability for environmental crimes remains weak and inefficient. Low environmental taxes do not contribute to the implementation of the polluter pays principle. Moreover, the need to stimulate the implementation of measures for environmental modernization of enterprises and strengthen their responsibility remains a declarative thesis. Therefore, the criminal liability of legal entities for committing environmental crimes remains quite controversial, requires more detailed study by the legislator, and the introduction of effective mechanisms for its prevention and overcoming in the context of foreign experience.

\section{Discussion}

The study showed that the issue of criminal liability of legal entities for environmental crimes in accordance with the Criminal Code of Ukraine cannot be considered definitively resolved. Taking into account the criminal law policy of the state, the postulates of legal theory and practice, the priorities of sustainable development and environmental protection legal approaches to the essence of the institution of responsibility of these entities should be reformed. When a legal entity is not held liable for its 
actions, it will affect both the competitiveness of the company itself and the environmental losses for the state in the future (Lubis et al., 2021). Scholars emphasize that if companies avoid responsibility for environmental crimes, law enforcement agencies will be considered incompetent because they will not comply with the rules established by law (Kisliy et al., 2021; Mackie, 2020). In this case, it can be argued about the declarative legality of the inevitability of punishment.

It also seems quite balanced for the state to establish comprehensive programmes with the allocation of adequate financial and human resources to prevent, investigate and prosecute legal entities for environmental crimes. The role of civil society institutions in the fight against environmental crime must also be qualitatively revised. Faure (2020) supported public involvement and raising legal awareness and activity of the population on identifying legal entities guilty of environmental crimes.

The research substantiated the need to improve the skills of state bodies, including prosecutors and judges, in order to more effectively prosecute and sanction environmental crime. It is also proposed to create a specialized unit in the national police of Ukraine to investigate environmental crimes. Husarov (2019) supported the reasonability of creating a specialized environmental police unit in Ukraine in 2019. The scholar substantiated the need to create environmental police units with a clear definition of tasks, functions, competencies and powers at the legislative level. It seems possible to gradually expand the powers, as well as administrative and jurisdictional activities in the field of environmental protection of regional units of the National Police (Kazanchuk, 2017:57).

There are current discussions on the vectors of legislative reforms in terms of comprehensive and interdisciplinary analysis with the involvement of experts in various fields of science (Roef, 2019), complemented by a comparative study of Ukrainian and foreign criminal law. Gavrilishin and Kozyreva (2018) supported the reasonability of legislative innovations. The scholars stated that the criminal liability of legal entities for environmental crimes has led to difficulties in law enforcement practice, which is currently undergoing reforms and qualitative changes in the institutions of the general and special parts of the Criminal Code of Ukraine. According to Malanchuk (2020), it is necessary to supplement the system of penalties for legal entities by applying judicial supervision over the activities of legal entities, and to provide a specific term of appropriate supervision.

The development of a set of preventive measures and concepts of internal self-discipline in the course of business activities by legal entities seems to be quite balanced. In this context, the main tasks of combating environmental crime are the following: 1) the creation of a system of appropriate information and analytical support for combating environmental crime in Ukraine based on the results of the analysis of 
reliable information about its condition and determinants; 2) development of criteria and constant analysis of monitoring data on the state of the environment; 3) minimization of the impact of criminogenic factors and practical possibilities of committing environmental crimes by legal entities.

The introduction of requirements for companies to develop compliance programmes at the legislative level should encourage companies to take proactive measures to prevent internal environmental risks (Dongmei, 2020). Approbation of this approach will allow increasing the effectiveness of punishment of legal entities and will correlate with the best European practices.

Moreover, a corporation that has taken appropriate steps to try to prevent wrongdoing should not be punished simply because the individual (the person in charge of the company) acted completely contrary to the corporate approach (Lennan, 2021). This should be recognized in any approach to corporate criminal liability for environmental crimes. In this sense, the strengthening of global law enforcement means that companies must be aware of the risks of law enforcement (Hamid et al., 2020). Timely self-assessment of environmental damage by legal entities remains a key step towards preserving the environment, minimizing the negative consequences of national and global environmental nature, and avoiding criminal liability.

\section{Conclusions}

In modern conditions, the idea of criminal liability of legal entities for environmental crimes finds a significant number of supporters in different countries under the influence of various criminal law doctrines. Both national and international legal regulation in this area is undergoing constant changes, taking into account the transformation of the environment, anthropogenic impact and the peculiarities of the investigation of this type of crime. Criminal liability of legal entities in general, and liability for environmental crimes in particular, remains the subject of lively discussions in scientific schools of different countries. At the same time, current trends towards the gradual destruction of entire ecosystems by economic activities necessitate strengthening the responsibility of these perpetrators around the world.

The content of criminal liability of the legal entity of the subjects under research is currently being transformed. In most EU member states that support a similar model of criminal prosecution to Ukraine, such types as personal liability and liability of a legal entity for environmental crimes coexist, not replacing or excluding each other. At the same time, the study revealed the shortcomings of criminal liability of legal entities 
for environmental crimes in the territory of the EU Member States. A comparative analysis of law enforcement practices allowed adapting the recommendations of the European Parliament to the vectors of reforming Ukraine's national legislation in this area. At the same time, the effective application of international regulatory, legal, and institutional tools requires the development and maintenance of the proper functioning of relevant national systems, an extended work at the national level.

The study resulted in a number of priority measures proposed to minimize the manifestations of criminal encroachments on the environment by legal entities in Ukraine. The need of internal corporate assessment of environmental risks of economic activity by legal entities as the most effective prevention tools is substantiated. At the same time, the results of approbation of such practice by Ukrainian enterprises will need further scientific analysis, especially in combination with the statistics of environmental crime in the country. Further research on the selected topic will also be based on the current state of fulfilment of Ukraine's international legal obligations on the comprehensive ecologization of production.

\section{Bibliographic References}

ADUA, Mustapha Ismail; ABDUL-HAMID, Oba Yusuf. 2018. "Corporate criminal liability in the realm of aviation security: the 2010 Beijing convention in focus" In: Journal of Transportation Security. Vol. 11, No. 2, pp. 53-63.

CAMPROUX DUFFRÈNE, Marie-Pierre; JAWORSKI, Veronique. 2021. Legal Paradigm Shifts for a New Environmental Law. Greens/European Free Alliance. Brussels, Belgium.

DONGMEI, Pan. 2020. "Criminal liability of legal entities in China: traditional approaches and modern choices" In: Russian Journal of Criminology. Vol. 14, No. 4, pp. 613-622.

EUROJUST. 2021. Report on Eurojust's Casework on Environmental Crime. Available online. In: https://www.eurojust.europa.eu/sites/default/ files/2021-01/report_environmental_crime.pdf. Consultation date: 11/04/2021.

EUROPEAN COMMISSION. 2020. Commission Staff Working Document. Evaluation of the Directive 2008/99/EC of the European Parliament and of the Council of 19 November 2008 on the Protection of the Environment through Criminal Law. European Commission. Brussels, Belgium. 
EUROPEAN COMMISSION. 2021. Delivering European Green Deal. Available online. In: https://ec.europa.eu/info/strategy/priorities-2019-2024/ european-green-deal/delivering-european-green-deal_en. Consultation date: $11 / 02 / 2021$.

EUROPEAN PARLIAMENT. 2021. European Parliament Resolution of 20 May 2021 on the Liability of Companies for Environmental Damage (2020/2027(INI)). Available online. In: https://www.europarl.europa. eu/doceo/document/TA-9-2021-0259_EN.html. Consultation date: 11/04/2021.

EUROPOL. 2020. Enterprising Criminals - Europe's Fight against the Global Networks of Financial and Economic Crime. European Union Agency for Law Enforcement Cooperation. Brussels, Belgium.

FAURE, Michael G. 2020. Environmental Liability of Companies, Study for the Policy Department for Citizens' Rights and Constitutional Affairs, June 2020. European Parliament. Brussels, Belgium.

FRENCH PENAL CODE. 1994. Available online. In: https://www. legislationline.org/download/id/8546/file/France_CC_am01202O_ fr.pdf. Consultation date: 11/02/2021.

GAVRILISHIN, Anatoliy; KOZYREVA, Valentyna. 2018. "The problems of criminal responsibility of legal entities: foreign experience" In: Scientific Works of National Aviation University. Series: Law Journal "Air and Space Law". Vol. 2, No. 47, pp. 160-165.

GOVERNMENT OF THE UNITED KINGDOM. 2021. Department for Environment Food \& Rural Affairs. Available online. In: https://www. gov.uk/government/organisations/department-for-environment-foodrural-affairs. Consultation date: 11/04/2021.

HAMID, Ruby; JOHN, Rani; CLARKE, James; DENTON, Ross; KING, Ronnie; DE ROUX, Hortense; CUFF, Cameron; BARROW, Amelia; MILLS, Nicholas; SHAH, Ria; CHITTY, Imogen; CHOW, Bertilla; LILLYCROP, Catherine. 2020. Corporate Crime: What Now for 2021? Available online. In: https://www.ashurst.com/en/news-and-insights/insights/ corporate-crime---what-now-for-2021. Consultation date: 11/02/2021.

HUSAROV, Serhiy M. 2019. Current issues of administrative jurisdiction of bodies, units of the national police for environmental protection in modern conditions. South Ukrainian Law Journal. Vol. 4, No, 3, pp. 136140 .

KAZANCHUK, Iryna D. 2017. "Competence of the National Police of Ukraine in relation to environmental protection and ecological safety in integration conditions" In: Our Law. Vol. 1, pp. 54-61. 
Yuliia O. Danylevska, Tetiana A. Sokur, Oleksandr M. Bodnaruk, Andrii V. Shevchuky Oleksiy V. Stratiy

KERRIGAN, Cristopher; CAMPBELL, James; BANYASZ, Dora; WINTER, Lewis. 2021. Trends in Corporate Crime and What You Can Expect in 2021. Available online. In: https://www.allens.com.au/insights-news/ insights/2021/02/trends-in-corporate-crime-and-ahead-for-2021/. Consultation date: 11/02/2021.

KISLIY, Anatoliy M; KYSLENKO, Dmytro P; TYMOSHENKO, Yuriy P; KALININA, Iryna V; HURINA, Dariia P. 2021. "Criminal provision of medical secret protection in Covid-2019" In: Ad Alta Journal of Interdisciplinary Research. Vol. 1, special issue 26, pp. 67-71.

LADYCHENKO, Viktor; YARA, Olena; ULIUTINA, Olena; GOLOVKO, Liudmyla. 2019. "Environmental liability in Ukraine and the EU" In: European Journal of Sustainable Development. Vol. 8, No. 2, pp. 261267.

LENNAN, Mitchell. 2021. "Evaluating the effectiveness of the EU environmental liability and environmental crime directives as implemented by Scotland and the rest of the United Kingdom" In: Journal of International Wildlife Law \& Policy. Vol. 24, No. 1, pp. 26-37.

LUBIS, Muhammad Ridwan; PUTRA, Panca Sarjana; SARAGIH, Yasmirah Mandasari. 2021. "Corporate criminal liability for criminal acts of corruption” In: Journal of Legal Update. Vol. 8, No. 1, pp. 48-59.

LYNCH, Michael J; STRETESKY, Paul B; LONG, Michael A. 2018. "Situational crime prevention and ecological regulation: A review and discussion" In: Annals of the American Academy of Political and Social Science. Vol. 679, pp. 178-196.

LYNCH, Michael J. 2020. "Green criminology and environmental crime: criminology that matters in the age of global ecological collapse" In: Journal of White Collar and Corporate Crime. Vol. 1, No. 1, pp. 50-61.

MACKIE, Colin. 2020. Environmental Due Diligence in Global Value Chains. European Coalition for Corporate Justice. Brussels, Belgium.

MALANCHUK, Petro. 2020. "Problems of criminal liability of legal entities" In: Actual Problems of Jurisprudence. Vol. 1, No. 21, pp. 202-205.

MINISTRY OF JUSTICE OF FINLAND. 2012. Finnish Criminal Code of 1889 (as Amended by Law no. 927/2012). Available online. In: https://www. finlex.fi/en/laki/kaannokset/1889/en18890039.pdf. Consultation date: 11/02/2021.

NELLEMANN, Christian (ed.). 2017. The Rise of Environmental Crime. A Growing Threat to Natural Resources, Peace, Development and Security, A UNEP-Interpol Rapid Response Assessment. UNEP. Nairobi, Kenya. 
OFFICIAL JOURNAL OF THE EUROPEAN UNION. 2008. Directive 2008/99/EC of the European Parliament and of the Council of 19 November 2008 on the Protection of the Environment through Criminal Law. Available online. In: https://eur-lex.europa.eu/legal-content/EN/ TXT/?uri=CELEX:32008L0099. Consultation date: 11/02/2021.

PORFIDO, Stefano. 2021. "The use of restorative justice for environmental crimes in the European Union's legal framework" In: Queen Mary Law Journal. Vol. 1, pp. 106-133.

ROEF, David. 2019. Corporate criminal liability. In: Johannes Keiler and David Roef (Eds.), Comparative Concepts of Criminal Law, 3rd edition (pp. 333-339). Antwerp, Intersentia.

SIRANT, Myroslava M. 2020. "Doctrinal approach to determination of environmental harm in the European Union and Ukraine" In: Law Bulletin. Vol. 14, pp. 76-84.

State Statistics Service of Ukraine. 2021. Justice and Crime. Available online. In: http://www.ukrstat.gov.ua/. Consultation date: 11/04/2021.

TURLOVA, Yuliya A. 2017. Criminal Law Impact on Environmental Crimes. Monograph. Znannya Ukrayiny. Kyiv, Ukraine.

UNITED NATIONS OFFICE ON DRUGS AND CRIMES. 2000. United Nations Convention against Transnational Organized Crime and the Protocols Thereto. Adopted by the UN General Assembly: 15 November 2000, by resolution 55/25. Available online. In: https://www.unodc.org/ unodc/en/organized-crime/intro/UNTOC.html. Consultation date: $11 / 02 / 2021$.

VERKHOVNA RADA OF UKRAINE. 1998. Convention on Environmental Protection by Means of criminal Law, (ETS N 172). Available online. In: https://zakon.rada.gov.ua/laws/show/994_560\#Text. Consultation date: $11 / 02 / 2021$.

VERKHOVNA RADA OF UKRAINE. 2001. Criminal Code of Ukraine of April 5, 2001, № 2341-III. Available online. In: https://zakon.rada.gov.ua/laws/ show/2341-14\#Text. Consultation date: 11/02/2021.

VERKHOVNA RADA OF UKRAINE. 2003. Civil Code of Ukraine of January 16, 2003, № 435-IV. Available online. In: https://zakon.rada.gov.ua/ laws/show/435-15\#n435. Consultation date: 11/02/2021.

VERKHOVNA RADA OF UKRAINE. 2013. The Law of Ukraine of May 23, 2013, № 314-VII «On Amending Certain Legislative Acts of Ukraine Concerning the Implementation of the Action Plan for the Liberalization 
Yuliia O. Danylevska, Tetiana A. Sokur, Oleksandr M. Bodnaruk, Andrii V. Shevchuky Oleksiy V.Stratiy

244 Criminal Liability of Legal Entities for Environmental Crimes: Problems of Law Enforcement Practice

of the European Union Visa Regime for Ukraine Regarding the Liability of Legal Entities». Available online. In: https://zakon.rada.gov.ua/laws/ show/314-18\#Text. Consultation date: 11/02/2021.

VERKHOVNA RADA OF UKRAINE. 2019. the Law of Ukraine No. 2697-VIII of 28.02.2019 "On the Basic Principles (Strategy) of the State Environmental Policy of Ukraine 2030" Available online. In: https://zakon.rada.gov. ua/laws/show/2697-19\#Text. Consultation date: 11/02/2021.

VERKHOVNARADAOF UKRAINE. 2020. Recommendations of Parliamentary Hearings on Priorities of Environmental Policy of the Verkhovna Rada of Ukraine for the Next Five Years. Available online. In: https://zakon. rada.gov.ua/laws/show/457-IX\#Text. Consultation date: 11/02/2021.

WHITE, Rob. 2018. "Green victimology and non-human victims" In: International Review of Victimology, Vol. 24, pp. 239-255. 

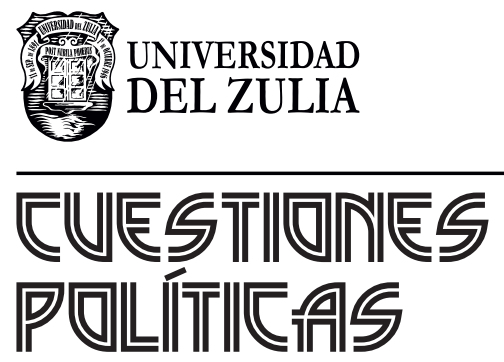

Vol. 39 N $^{\circ} 71$

Esta revista fue editada en formato digital y publicada en diciembre de 2021, por el Fondo Editorial Serbiluz, Universidad del Zulia. Maracaibo-Venezuela 